\title{
Abordagem
}

\section{Elementos para redução da dívida externa brasiléira}

O ano de 1989 foi apresentado de forma alentadora para os países endividados. A mudança de governo nos Estados Unidos da América do Norte e a reunião de cúpula dos sete países industrializados, em Paris, surgiam como fatores de inflexão da negociação da dívida externa dos países em desenvolvimento.

Efetivamente, o governo norte-americano, após a posse do presidente Bush, anunciou as linhas gerais do plano Brady. Em julho, intençōes convergentes foram divulgadas após a reunião de cúpula do Grupo dos sete. Apesar das intençōes manifestas, o impasse decorrente da dívida externa brasileira prossegue. Os serviços da dívida continuam sangrando os resultados do balanço comercial e as fontes de recursos novos continuam inacessíveis.

A Área de Concentração de Assuntos Internacionais do IEA se debruçou sobre esta questão. A discussão baseou-se num documento preparado por Geraldo Forbes, membro do Conselho Diretor. Além deste, participaram da discussão os professores Jacques Marcovitch, André Franco Montoro Filho, Ruy Aguiar da Silva Leme, José Augusto Guilhon de Albuquerque, Carlos Alberto Longo e Stephan Kanitz.

À guisa de contribuição foram apresentadas as seguintes consideraçōes preliminares, recomendações e conclusão.

\section{Consideraçōes Preliminares}

1. A dívida externa brasileira está consubstanciada em contratos legais, cujos termos só devem ser alterados na medida em que sua cega observância contraria os princípios gerais de direito, e sobretudo o princípio rebus sic stantis, e na medida em que ameaça a integridade do país e o bem-estar de seu povo.

2. O objetivo inegável desta proposta é a redução dos encargos da dívida, a imposição de limites à flutuação dos juros, a extensão dos prazos dos compromissos, a adaptação das condiçōes à real capacidade de repagamento do país, a eventual diminuição do montante devido pela aplicação de certas taxas de descontos, o estímulo relativo ao investimento estrangeiro no paés.

3. A proposta considera que os elementos do chamado "Plano Brady" constituem o definitivo reconhecimento pelos países credores da necessidade de serem alterados os termos do endividamento e considera, por isso mesmo, desnecessário aduzir, ainda uma vez, argumentos de caráter político, econômico ou social, a uma questão tão longa e amplamente debatida e a que é hoje uma certeza indubitável. 
4. Teve-se presente a noção de que o Brasil deve envidar todos os esforços para integrar-se no quadro das grandes potências econômicas. Teve-se também presente o fato de não ser bastante, para nossos planos de desenvolvimento, a simples redução do principal e juros da dívida. O País precisará de novos fluxos de financiamento e investimento e por isso não pode, nem quer, hostilizar a comunidade financeira internacional.

5. Por outro lado notou-se que, no atual contexto, esses fluxos só diminuíram e tendem a se reduzir ainda mais. Por isto considerou-se que qualquer que seja a solução adotada, os bancos não voltariam imediatamente a conceder novos empréstimos e que a melhor receita para o restabelecimento dos fluxos financeiros será a reestruturação radical do atual endividamento e o relançamento do país em novo surto de progresso.

6. Entendeu-se que, devido à preemência de tempo nas presentes circunstâncias econômicas e políticas e, ainda, que devido ao grande número de credores e a sua diversidade, a reestruturação desejada não pode ser o resultado de um processo de negociação entre desiguais, processo esse sempre demorado e imperfeito. A forma de reestruturação do endividamento deve ser prontamente declarada de forma impositiva pelo Brasil, levando todavia em conta os interesses $\mathrm{e}$ a capacidade financeira de seus credores, tanto quanto as realidades do mercado internacional.

\section{Recomendações}

\section{Quanto aos Juros da Dívida Corrente}

a) Deve ser declarado um teto máximo para a taxa de juros, de forma que esta não ultrapasse, todos os seus elementos considerados, a quantia de $12 \%$ ao ano. Tudo o que exceder, por efeito de flutuações ou outro, esse limite não é considerado devido e por isto não será pago.

b) Tendo em vista o alto valor dos encargos da dívida em relação a uma expectativa razoável de saldos comerciais, deve ficar estabelecido que dos juros vincendos só um percentual (de início a sua terça parte) poderá ser remetido no pagamento para o exterior. $O$ restante será transformado em Bônus Externos (v. características em 2 iii abaixo) sem ágio ou desconto de qualquer natureza.

\section{Quanto à Dívida Vincenda e Vencida}

a) O País compromete-se a vender divisas para remessa de fundos recebidos no vencimento do principal da dívida externa, desde que as suas reservas líquidas sejam iguais a pelo menos seis meses de importações, respeitado o nível estratégico mínimo de 15 bilhões de dólares. Sempre que as reservas estiverem abaixo deste nível, os credores poderão utilizar as seguintes opções para aplicação de seus fundos:

i) Depósitos em cruzados novos na Caixa Econômica Federal. Os depósitos, com 20 anos de prazo fixo, são corrigidos pelo mesmo índice das Cadernetas de Poupança e pagam juros de 5\% a.a., semestralmente. Juros e principal são conversíveis e remissíveis pela taxa do dólar do dia de sua liberação. Nâo são transferíveis. 
ii) Compra de Bônus Internos. Denominados em moeda nacional, com 20 anos de prazo, esses bônus pagam $4 \%$ de juros anualmente, são corrigidos pelo mesmo índice das Cadernetas de Poupança e são livremente transacionáveis depois de $\mathbf{1 0}$ anos de sua emissâo. Remessa de juros permitida a cada vencimento. A remessa do principal é permitida após 20 anos.

iii) Compra de Bônus Externos. Denominados em dólares, com 25 anos de prazo, os bônus pagam juros de $3 \%$ a.a. O preço dos bônus é igual a $160 \%$ de seu valor de face para traduzir o valor real da dívida.

iv) Conversão dos Créditos em Investimentos em Empresas Privadas. Os créditos são conversíveis com um desconto mínimo de $60 \%$ de seu valor, segundo um sistema de leilōes mensais. Os investimentos são objeto de registro, mas não poderão ser revendidos e retornados antes de 25 anos. O prazo de carência para remessa de eventuais dividendos para o exterior é de 6 anos.

v) Conversão dos Créditos em Debêntures "Ex" de Companhias Estatais. A conversão será feita após um desconto de $50 \%$ do valor do crédito. As debêntures pagarão juros máximos de $6 \%$ a.a. e, após pelo menos 15 anos, serāo conversíveis em açōes preferenciais sem direito a voto. As açōes resultantes são livremente negociáveis e o produto de sua eventual venda pode ser remetido, uma vez convertido à taxa do dólar do dia da transação mobiliária. Todas as companhias estatais devedoras em moeda estrangeira estarão autorizadas a emitir debêntures por um valor equivalente a $50 \%$ de sua dívida externa.

vi) Renovação dos Empréstimos com Estatais. Possibilidade aberta apenas aos vencimentos da dívida das companhias estatais. Os novos empréstimos terão prazo de vencimento de 30 anos com 20 anos de carência e não poderāo ter qualquer garantia adicional à obrigaçāo do tomador de recursos. Tais empréstimos pagarâo juros fixos de $3 \%$ a.a. e serão denominados em dólares americanos.

b) Ficam excluídos da regra acima os vencimentos de nossos bônus externos aos quais é sempre assegurado o pontual pagamento independentemente do nível de reservas.

c) Os depósitos feitos à ordem de credores junto ao Banco Central não rendem juros. Após 30 dias de sua efetivação, seu valor será traduzido de moeda estrangeira para moeda nacional. A partir desta data não serão corrigidos.

\section{Quanto a Incentivos para o Retorno de Capitais Clandestinos de Bra-} sileiros

a) Serão emitidos Bônus "Ex." ao portador, denominados em moeda nacional, com prazo de cinco anos e indexados em dólares, pagando juros de $8 \%$ a.a. As aquisições serão feitas pelo valor de face se o pagamento for efetivado por venda de câmbio e por $120 \%$ do valor de face se for efetuado por entrega de fundos em cruzados novos. Os adquirentes que desejam aumentar sem qualquer penalidade fiscal sua declaração de bens 
pelo valor do Bônus "Ex." deverão depositá-los por 380 dias em instituiçōes bancárias devidamente credenciadas.

\section{Quanto à Relação com as Instituiçōes Financeiras Internacionais}

a) O País não remeterá nos próximos cinco anos nada além do que receber em novos créditos dos organismos internacionais. Sempre que a "balança de pagamentos" deste setor for desfavorável ao Brasil, as remessas serão suspensas e os fundos correspondentes depositados no Banco Central, que lhes atribuirá juros de $3 \%$ a.a.

\section{Outras Disposiçōes Complementares}

a) Novos empréstimos externos a filiais de companhias estrangeiras só poderão ser feitos à taxa máxima de $6 \%$ a.a. quando denominados em dólares. As recipientes pagarāo uma taxa de $2 \%$ a.a. ao Banco Central do Brasil. Incorrerão nesta regra também os empréstimos "em ser" que vierem a ter alterados quer o seu credor, quer o seu devedor.

b) Os devedores de todos os empréstimos estrangeiros vencidos e não pagos passarão a pagar sobre eles uma taxa anual de $10 \%$ a.a. ao Banco Central do Brasil, ou os terão transformados em investimentos estrangeiros pelo valor de face.

c) Ficará dissolvido o Comitê dos Bancos Credores.

d) O País negociará, eventualmente, a compra de seus débitos à taxa que lhe convier, com o credor que lhe convier, independentemente de audiência e concordância dos outros credores.

e) O País está, em princípio, interessado em tomar garantias ou empréstimos dos oganismos financeiros internacionais para a compra, nas condiçōes que nos sejam vantajosas, dos débitos vincendos.

\section{Conclusão}

A resolução do impasse da dívida externa brasileira resultará da existência de um governo legítimo e com credibilidade no País e no Exterior. Depende também de uma proposta tecnicamente viável e de um encaminhamento político pertinente. Sem estas três pré-condiçōes as janelas de oportunidades que eventualmente possam surgir não serão aproveitadas. $O$ discurso dos governos dos países industrializados revela intençōes generosas mas consolidam o status quo. Uma estratégia política de negociação, sustentada tecnicamente, é necessária para a solução do impasse. Um impasse que estagna e degrada no presente e ameaça cada vez mais no futuro. 